\title{
DECAPACITATION FACTOR PURIFICATION WITH LIPID SOLVENTS
}

\author{
H. N. GHERNOFF* AND W. R. DUKELOW $\dagger$ \\ Oregon Regional Primate Research Center, \\ Beaverton, Oregon 97005
}

\begin{abstract}
Summary. Decapacitation factor (DF) was extracted from rabbit seminal plasma with a chloroform : methanol solution resulting in a considerable purification, based on dry weight.
\end{abstract}

In 1957, Chang reported the presence of a substance in the seminal plasma of several mammalian species which had the ability to reverse the capacitation process (decapacitation factor or DF). Bedford \& Chang (1962) were partially able to purify DF by ultra-centrifugation. Since that time, a great deal of effort has been given to the purification, isolation and identification of this substance (Chernoff, Pinsker, Dukelow \& Williams, 1966; Dukelow, Chernoff \& Williams, 1966a, b, 1967a, b; Pinsker \& Williams, 1967; Williams, Abney, Chernoff, Dukelow \& Pinsker, 1967; Dukelow \& Chernoff, 1968). These reports have demonstrated that $\mathrm{DF}$ can be destroyed by crude amylase preparations but is stable to neuraminidase, pronase and glucose oxidase; that it exists in a wide variety of species but is not present in all mammalian seminal plasma; that it can be reduced in molecular size with pronase without destroying DF activity, and that it is resistant to destruction by heat and cold.

Semen was collected from rabbits with an artificial vagina. These samples were centrifuged at $862 \mathrm{~g}$ for $15 \mathrm{~min}$ to remove the sperm cells, diluted with an equal volume of Krebs Ringer phosphate (KRP) and then frozen until a pooled volume of $75 \mathrm{ml}$ had been accumulated.

All reagents used in these extractions were analytical grade from Mallinckrodt Chemical Company, St Louis, Missouri.

The seminal plasma was extracted with $200 \mathrm{ml}$ of chloroform:methanol $(2: 1 \mathrm{v} / \mathrm{v})$ as shown in Text-fig. 1. This extraction was repeated three times and the extracts were combined. These combined extracts were reduced to dryness and resuspended in KRP to provide a sample isotonic to spermatozoa for biological assay. This was designated the chloroform:methanol (CंM) fraction. The nonlipid residue was evaporated to approximately $15 \mathrm{ml}$ and called the NLR sample.

In an attempt at further purification, the KRP resuspended rabbit chloroform : methanol extract was extracted three times with redistilled, low boiling $\left(40\right.$ to $\left.60^{\circ} \mathrm{C}\right)$ petroleum ether $(1: 10 \mathrm{v} / \mathrm{v})$. The petroleum ether extracts were combined and evaporated to dryness. This residue was triturated with $10 \mathrm{ml}$

* Present address: Laboratory Services, Veterans Administration Center, Prescott, Arizona 86301. $\uparrow$ Present address: Department of Biochemistry, University of Georgia, Athens, Georgia 30601. 
$\mathrm{KRP}$ and the decanted KRP was termed the petroleum ether (PE) fraction. The original aqueous phase (AP), remaining after the petroleum ether extraction, was evaporated to $15 \mathrm{ml}$ on a steam bath.

In the DF assays, New Zealand White rabbits were used. The assay procedure has previously been described in detail (Dukelow et al., 1966b). Basically a doe was mated three or four times and capacitated spermatozoa were surgically recovered $12 \mathrm{hr}$ later from her uterus. These spermatozoa were washed, counted and resuspended in KRP. They were then incubated with the test sample $\left(1 \mathrm{mg}\right.$ dry weight $/ 10^{5}$ spermatozoa) for $20 \mathrm{~min}$ at $37^{\circ} \mathrm{C}$. The incubated spermatozoa were then centrifuged, resuspended in KRP and $0.5 \mathrm{ml}$ of the sperm

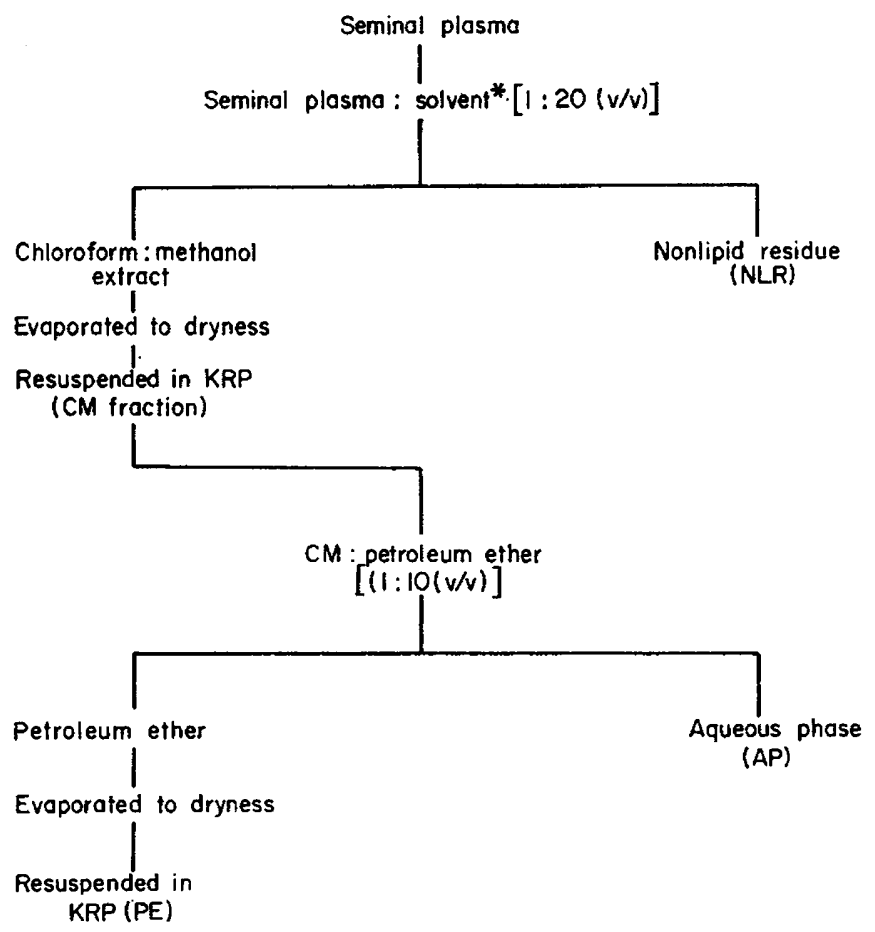

TEXT-FIG. 1. Sequence for the extraction of DF with organic solvents from rabbit seminal plasma. $*$ Solvent $=$ chloroform : methanol $[2: 1(\mathrm{v} / \mathrm{v})]$.

suspension $\left(2.5 \times 10^{4}\right.$ spermatozoa) was inseminated into one oviduct of a doe injected $12 \mathrm{hr}$ previously with luteinizing hormone. The contralateral oviduct received an equal number of untreated capacitated spermatozoa.

To ensure that the DF active preparations were not toxic to the spermatozoa, decapacitated spermatozoa were 'recapacitated' by a second in utero incubation. Approximately $4 \mathrm{hr}$ before ovulation (i.e. $6 \mathrm{hr}$ after $\mathrm{LH}$ injection) $8 \times 10^{5}$ spermatozoa were injected into the uterine horn of a doe. Twice-washed ejaculated spermatozoa were inseminated into the opposite uterine horn as a control for the ability of the doe to capacitate spermatozoa (Dukelow et al., 1966b). 
Assays for DF activity in the extracted fractions are shown in Table 1. The chloroform : methanol fraction has DF activity and the lack of sperm toxicity is shown by the successful recapacitation of the rabbit spermatozoa. The nonlipid residue from seminal plasma had no DF activity ( $58.5 \%$ fertility). Neither the petroleum ether nor the aqueous phase fractions had DF activity ( 31.6 and $62.5 \%$ fertility, respectively).

The dry weight of $200 \mathrm{ml}$ of seminal plasma was $6 \cdot 28 \mathrm{~g}$, while the CM fraction of this same $200 \mathrm{ml}$ of seminal plasma had a dry weight of $0 \cdot 16 \mathrm{~g}$. Thus, a 37-fold decrease in dry weight was obtained.

\section{TABLE 1}

DF-ACTIVITY ASSAY IN TERMS OF NUMBERS OF FERTILIZED AND NON-FERTILIZED OVA RECOVERED 24 HR POST-INSEMINATION FROM OVIDUGTS OF NEW ZEALAND WHITE VIRGIN DOES

\begin{tabular}{|c|c|c|c|c|c|}
\hline Fraction* & $\begin{array}{c}\text { Text } \\
\text { abbreviation }\end{array}$ & $\begin{array}{l}\text { No. } \\
\text { oviducts }\end{array}$ & Fertile & Non-fertile & $\%$ Fertile \\
\hline $\begin{array}{l}\text { Control } \\
\text { Chloroform: methanol } \\
\text { Nonlipid residue } \\
\text { Petroleum ether } \\
\text { Aqueous phase }\end{array}$ & $\begin{array}{l}\overline{\mathrm{CM}} \\
\mathrm{NLR} \\
\text { PE } \\
\mathrm{AP}\end{array}$ & $\begin{array}{r}28 \\
6 \\
9 \\
5 \\
4\end{array}$ & $\begin{array}{r}33 \\
1 \\
21 \\
6 \\
8\end{array}$ & $\begin{array}{r}63 \\
20 \\
15 \\
13 \\
5\end{array}$ & $\begin{array}{r}34 \cdot 4 \\
4 \cdot 8 \\
58 \cdot 5 \\
31 \cdot 6 \\
62 \cdot 5\end{array}$ \\
\hline \multicolumn{6}{|c|}{ Recapacitation of spermatozoa decapacitated with chloroform : methanol fraction } \\
\hline $\begin{array}{l}\text { Ejaculated sperm control } \\
\text { Chloroform: methanol }\end{array}$ & $\overline{\mathrm{CM}}$ & $\begin{array}{l}7 \\
7\end{array}$ & $\begin{array}{l}32 \\
11\end{array}$ & $\begin{array}{l}3 \\
9\end{array}$ & $\begin{array}{l}91 \cdot 5 \\
55 \cdot 0\end{array}$ \\
\hline
\end{tabular}

* Test sample fraction incubated with capacitated spermatozoa.

This work demonstrates that decapacitation factor can be extracted from seminal plasma with a chloroform : methanol solution; however, this activity cannot be recovered after a second extraction with petroleum ether. This method of extracting DF is more efficient and less time consuming than earlier ultracentrifugation and column chromatography techniques.

The present work was supported by grants from the Lalor Foundation, Population Council and the National Institutes of Health.

The paper carries the Publication Number 352 of the Oregon Regional Primate Research Centre.

\section{REFERENCES}

Bedrord, J. M. \& Chang, M. C. (1962) Removal of decapacitation factor from seminal plasma by high speed centrifugation. Am. 7. Physiol. 202, 179.

Chang, M. C. (1957) A detrimental effect of seminal plasma on the fertilizing capacity of sperm. Nature, Lond. 179, 258.

Chernoff, H. N., Pinsker, M. C., Dukelow, W. R. \& Williams, W. L. (1966) Purification of sperm antifertility factor. Fedn Proc. Fedn Am. Socs exp. Biol. 25, 284.

Dukelow, W. R. \& Ghernoff, H. N. (1968) Primate sperm survival and capacitation in a foreign uterine environment. Am. F. Physiol. (In press).

Dukelow, W. R., Ghernoff, H. N. \& Williams, W. L. (1966a) Enzymatic characterization of decapacitation factor. Proc. Soc. exp. Biol. Med. 121, 396. 
Dukelow, W. R., Chernoff, H. N. \& Williams, W. L. (1966b) Stability of spermatozoan decapacitation factor. Am. J. Physiol. 211, 826.

Dukelow, W. R., Chernoff, H. N. \& Williams, W. L. (1967a) Fertilizable life of the rabbit ovum relative to sperm capacitation. Am. F. Physiol. 213, 1397.

Dukelow, W. R., Chernoff, H. N. \& Williams, W. L. (1967b) Properties of decapacitation factor and presence in various species. F. Reprod. Fert. 14, 393.

Pinsker, M. C. \& Williams, W. L. (1967) Properties of a spermatozoan antifertility factor. Archs Biochem. Biophys. 122, 111.

Williams, W. L., Abney, T. O., Chernofp, H. N., Dukelow, W. R. \& Pinsker, M. G. (1967) Biochemistry and physiology of decapacitation factor. F. Reprod. Fert., Suppl. 2, 11. 